\title{
Investigating the Relationship Between Country Competitiveness and Financial Market Development in Times of Crisis
}

\author{
George Galanos ${ }^{1}$, Thomas Poufinas ${ }^{2} \&$ Charalampos Agiropoulos ${ }^{1}$ \\ ${ }^{1}$ Department of International and European Studies, University of Piraeus, Piraeus, Greece \\ ${ }^{2}$ Department of Economics, Democritus University of Thrace, Komotini, Greece \\ Correspondence: Charalampos Agiropoulos, Department of International and European Studies, University of \\ Piraeus, Piraeus, Greece.
}

Received: July 19, 2021

Accepted: August 16, 2021

Online Published: September 7, 2021

doi:10.5430/rwe.v12n4p38

URL: https://doi.org/10.5430/rwe.v12n4p38

\begin{abstract}
A country's competitiveness depends on many factors related to general governance, effectiveness of markets, social development, and business perspectives. The role of financial markets for economic growth has been the subject of many scientific studies; most of them concluded that a well-developed financial system should improve the efficiency of financing decisions, favouring a better allocation of resources and thereby economic growth. The financial crisis that started in the summer of 2007 is still testing the strength of the global economic system. It started in the financial sector, but is now having an important impact on the real economy. The aim of this paper is to investigate the relationship between a country's financial market development and its competitiveness in particular in times of crisis, with the use of a series of econometric models. We find evidence that financial market development is affected (with the anticipated sign of impact) by the Global Competitiveness Index, the GDP per capita and the (un)employment level of a country. It is also related (with an unexpected direction of impact) with the foreign market size and exports, as well as infrastructure. Our findings can be used by the policymakers of countries which wish to improve their competitiveness so as to steer the determining variables in the desired directions and approach their desired competitiveness levels.
\end{abstract}

Keywords: competitiveness, financial markets, crisis, economic growth

JEL Classification: G10

\section{Introduction}

The scientific debate on the term competitiveness, as it was recorded at the end of the 20th century, was boosted in the 1980s on both sides of the Atlantic and in the developing countries. This has been mainly the result of technological developments and the gradual widening of the phenomenon of globalisation (Govindarajan \& Gurta, 2001) in the wider economic realm (Reinert, 1995). In the 1990s and early 21 st century there was a change in the fundamental basis of competition in many areas of business activity, (Tapscott, 2001), setting new ground for the scientific debate on the interpretation of the term competitiveness. Nowadays, it has another dimension since we are now seeing its presence also among the states. 'National' competitiveness could be defined as 'the ability of a state to create, produce and distribute products and services on the international market while at the same time it has an increase in remuneration from sales of finished goods and raw materials' (Scott \& Lodge, 1985). As a result, the term 'competitiveness' includes a set of multivariable factors in microeconomic and macroeconomic levels, such as social cohesion, business culture, natural resources, energy, social capital, labour market, education and skills, infrastructure, access to and the level of research and development, technology, the economic and business environment, the level of entrepreneurship, and innovation (Ezeala \& Harrison, 1999) and finally the financial sector, which now holds a prominent place in the scientific debate on measuring the competitiveness (Jochem, 2016) as one of the key factors for both economic development and competitiveness. According to the above, the aim of this paper is to investigate the relationship between a country's competitiveness and financial market performance in time of crisis. 


\section{Literature Review}

Considering a more wide framework of the concept of competitiveness, one could possibly suggests that competitiveness runs across the ability to cost-effectively sell products and services in conditions of international competition. This definition is theoretically applicable to a business, an industry, or even a country. However, recent studies have distinguished the definition on the microeconomic and macroeconomic levels, concerning the competitiveness of companies and states. Looking into the microeconomic perspective a firm which manages to survive and to increase its market share within the industry it belongs is likely to be considered as competitive (Porter, 1990). From the other hand, on a macroeconomic level, competitiveness is interpreted as the extent of which a country is able to produce goods and services that can meet market requirements, while at the same time maintains or increases the actual income of its workers (Cohen et al 1994). Considering this approach, workers appear for the first time to be a direct component in shaping and assessing the competitiveness of a state. Another argument concerning this term is the OECD "Program on Technology and the Economy" OECD, TEP (1992), which interprets international competitiveness as of a country in a fully liberalised market can continuously improve the standard of living of its citizens.

Considering macroeconomic interpretations it is obvious that there is a clear differentiation in the interpretation of the term: on the microeconomic level, we focus on market share and productivity, while on the macroeconomic level each country focuses on its level of competitiveness, on its citizens and their standards of living. At the same time, more recent business strategy discussions (Mitchell, 2000) (strategic management) have determined that a company's strategic competitiveness is achieved when it manages to formulate and implement a value-creating strategy. In this way, when a company applies methods that other rival companies cannot duplicate or that are too expensive to imitate, then this company has achieved a competitive edge within the market, maximising its competitiveness (Martin 2001).

According to international literature, the best-known indicators for measuring competitiveness are those of the World Economic Forum (WEF) and the International Institute of Management Development (IMD). These two indicators are general and comprise several different dimensions and sub-criteria. In general, the approach of these two indicators is global in terms of the image of each country's competitiveness: a) the WEF's Global Competitiveness Index, is based on objective and subjective criteria, mainly derived from the processing of questionnaires submitted to senior executives, in the context of surveys conducted by the World Economic Forum. For some variables, the objective criteria that are used are converted to a scale similar to that of the subjective ones in order to make summations, which undoubtedly lead to simplifications. However, both the indicator and the methodology employed are considered fairly reliable, b) the IMD Global Competitiveness Index: The IMD index is also used to explore competitiveness and assumes that the creation of wealth originates on the enterprise level; research in this field is focused on the 'Competitiveness of Enterprises' instead of states. At the same time, businesses operate in a national environment that strengthens or limits their ability to compete domestically or internationally. The estimations are mainly based on subjective questionnaire responses by business executives, which inevitably create reservations about the validity of the rankings.

A key feature of these two systems of measuring competitiveness is their approach through a system of indicators reflect the course of the economy of each country under consideration. In particular, both systems are based on an analysis of individual indicators. A common feature of these systems is the use of a series of indicators and parameters that influence, and in a way flatteringly determine productivity along with the general welfare of the population, without neglecting the need for sustainable economic growth and prosperity.

The majority of the proposed models classifies a number of indicators into categories. Although the calculation of these indicators and groups is implemented individually, it should be noted that they are not independent of each other, and in many cases, they are strongly associated whilst any change in one significantly affects the other. Obviously, it is expected that any change on a case-by-case basis will affect other indicators with a different way. Ultimately it is worth to mention that not all of the criteria are applied in the same way in all countries; for instance, it is easy to understand that the size, the structure, and the nature of a small economy are different, from those of the United States. In any case, both key indicators are based on sub-factors, each of which has been examined in a variety of scientific studies. Particularly, Acs \& Szerb, Bosma \& Levie (2010), Rebernik et al. (2015), Reynolds et al. 2002; 2005 have noted that entrepreneurship is considered a powerful factor that influences competitiveness. Various studies have shown that the quality of a country's institutions, determined by the legal and administrative framework, within which individuals, businesses and governments interact to create wealth, has proven to be a factor of economic growth and competitiveness, see also Acemoglu et al. (2002), Rodrik et al. (2002) and Miller et al (2014). 
Canning \& Pedroni (2004) and Calderon \& Serven (2004) have shown that competitiveness is mainly affected from different factors such as: infrastructure and, in general, the quality of technological and transport infrastructure. At the same time, several macroeconomic effects have been analysed in the literature. Goodfriend (2007) and Temple (2000) have explored the effects of low and moderate inflation rates, Reinhart and Rogoff (2010) have analysed the impact of public debt levels as well as the impact of the tax level. The structure of taxation and the way the government spends money have been analysed by Johansson et al. (2008), among others.

In addition, both Jones \& Teece (1988), and Buckley (1988-1990), as well as Nelson (1992), and Francis (1989), have demonstrated through their studies that competitiveness is a factor that greatly determines a country's ability to stand and develop in a global economic environment (ReiLjan et al 2000), while, at the same time, there is a plethora of scientific research studies that directly links the issue of competitiveness to the components of economic growth. Choudhri \& Globerman (2002) have concluded that there is a combination of competitiveness and international competitiveness. A strong correlation amongst unit labour costs and competitiveness and growth has been detected (Fagerberg, 1998; Yap, 2004), and it is directly related with the form of competitiveness to economic growth through the real effective exchange rate (REER) and unit labour cost (ULC).

Consequently, in many scientific studies there is a clear identification of the factors that make up the systems of measuring competitiveness and economic growth, e.g. Harrison (1996), Bosma \& Levie (2010), Rebernik et al. (2015). International indicators constitute an emerging 'metric' of the competitiveness of countries; indirectly they tend to function as multiple 'international observatories' whose assessments will be of great concern to us in the future. The indicators are produced by international bodies, which are generally reputable and continuous. The publication of the indicators, regardless of reliability, influences the perception of international investors, businesses, institutions, governments, and the international community for each country, with significant implications. This should be the subject of regular monitoring and scrutiny. The indicators' structure and reliability tends to improve over time, but in any case all the individual factors that compose competitiveness are very much in line with what economic theory calls growth.

\section{Competitiveness and the Financial Sector}

The link between the notions of financial system development and economic growth/development was introduced in the 1970s by Shaw (1973) and McKinnon (1973). A more empirical, experimental effort appeared in the 1990s with the research of Kind \& Levine (1993a, b), Levine et al (2000), Levine et al (2004), De Haas (2001) and a number of other studies that have shown that the level of financial growth has beneficial effects on economic growth, technological progress, and capital accumulation.

The primary function of the financial system is the transfer of capital from various sources of savings to investors. The mediating role of banks in the economy, apart from the mobilisation of savings, consists in collecting and utilising information on the business environment and the economic outlook and, consequently, in the analysis and better management of risk. The financial system consists of three main players: financial institutions, the market, and investors (including depositors). Companies generate demand for cash and investors supply it. The government is not a direct player, but it operates so as to monitor banks, provide market infrastructure, and protect investors when financial institutions are insolvent. Financial institutions are intermediating in the demand and offer of cash in indirect funding. As a financial market develops, it can provide direct financing to businesses. In the simplest case, the funds will flow from investors to businesses; however, not all investors may be willing to invest directly in businesses because of the higher risk and lack of information. At the same time, not all businesses will be able to benefit from the capital market, owing to the lack of security, information, or reliability. As a result, financial markets will need to develop different ways for capital to flow from investors to businesses, and the ability of financial institutions to respond to such needs will become increasingly important and will be a factor of competitiveness. Financial institutions are often divided into wholesale and retail segments, in order to address the different needs of a wide customer base.

Based on the above, on a theoretical level and through the various studies mentioned above, we can see that the financial system contributes to economic growth through factors such as lowering transaction costs, providing faster and fuller information, and facilitating capital transfer and moves for either savings or investment purposes (Levine 2000). At the same time, scientific analysis has demonstrated that the optimal functioning of the financial sector also contributes to other parameters associated with economic growth and competitiveness, such as the efficiency and effectiveness of production factors, and productivity (Rioja, and Valev 2004, Lozano and Pastor 2006). In these studies the scholars conclude that the efficient operation of the banking system has a favourable effect on economic growth. Chortareas et al. (2010), looking at data from nine Latin American countries, find that bank productivity 
(measured by a Malmquist index) is higher in countries with more developed financial systems (at the same time there are some signs of two-way causality). Arestis et al. (2010), analysing the results of some 60 published studies, find that any differentiation of quantitative estimates is largely due to the type of data and to the different variables used as financial development indicators.

Recently, Alomary et al (2019) examine the contribution of financial market development in competitiveness (growth) of developed and higher income countries for the period 2009 - 2017 to find that financial market development, trade openness, labour market efficiency and technological readiness are positive and significant, whereas market size is positive but insignificant.

In conclusion, based on the above, a significant body of literature has been developed on the importance of banks for the operation of the economic system, as well as on their specific role, which is decisive for the long-term process of economic growth and thus competitiveness.

Our paper studies the impact of certain competitiveness proxies to the financial market development. The findings can be used to draft proposals for potential policies that can be followed, supported by quantitative evidence, which is one step ahead of the existing literature in the area that simply acknowledges the problematic, without necessarily coming forward with ways to overcome it. According to our results it has been empirically showed that a country needs to seriously consider its competitiveness in order to secure the desired financial market growth and there lies the contribution of our research on this topic.

\section{Data, Variables, and Methodology}

\subsection{Data}

The dataset we used comes mostly from World Economic Forum (WEF, 2017). More specifically, the Global Competitive Index (GCI), the Foreign Market Size Index (FMI), the Infrastructure Index (INFR), the Labour Market Efficiency Index (LME) and Financial Market Development (FM) have been derived from the Global Competitiveness Report which was published in 2017 by the World Economic Forum. All the above indices are scaled and range from 1 to 7 (best).

The control variables set includes Unemployment rate (UN), the real Gross Domestic Product per capita (GDPpc) and the total Exports of goods and services (EXP) as a percentage of GDP. The above control variables have been derived from the World Bank open access dataset (2019) and used to calibrate the proposed model as a set of macroeconomic variables.

The data set used spans the period 2006-2017 and includes 28 European countries organising a panel data set where $\mathrm{n}=28, \mathrm{~T}=12$ and total number of observations $\mathrm{N}=336$. The period was chosen based on data availability for all key variables and for all 28 European countries. These countries are: Austria, Belgium, Bulgaria, Croatia, Cyprus, Czech Republic, Denmark, Estonia, Finland, France, Germany, Greece, Hungary, Ireland, Italy, Latvia, Lithuania, Luxembourg, Malta, Netherlands, Poland, Portugal, Romania, Slovakia, Slovenia, Spain, Sweden and the United Kingdom.

\subsection{Variables}

For the examined models the paper considers as dependent variables the Financial market development (FM) while country competitiveness proxies have been considered as independent variables along with the macroeconomic variables. The following Table 0 presents the independent and control variables along with a short description and the source where the dataset has been derived.

Table 1. Variables selection

\begin{tabular}{ccccc}
\hline Variable & Coding & Type & Description & Source \\
\hline $\begin{array}{c}\text { Financial Market } \\
\text { Development }\end{array}$ & FM & Dependent & $\begin{array}{c}\text { The ability of the financial sector to allocate the } \\
\text { resources to entrepreneurial or investment projects } \\
\text { with highest expected IRR }\end{array}$ & $\begin{array}{c}\text { World } \\
\text { Economic } \\
\text { Forum }\end{array}$ \\
\hline $\begin{array}{c}\text { Global } \\
\text { Competitive Index }\end{array}$ & GCI & Independent & $\begin{array}{c}\text { The ability of a country to achieve sustained high } \\
\text { rates of growth in gross domestic product (GDP) per } \\
\text { capita }\end{array}$ & $\begin{array}{c}\text { World } \\
\text { Economic } \\
\text { Forum }\end{array}$ \\
\hline
\end{tabular}




\begin{tabular}{|c|c|c|c|c|}
\hline $\begin{array}{l}\text { Foreign Market } \\
\qquad \text { Size }\end{array}$ & FMI & Independent & $\begin{array}{l}\text { The exports of goods and services obtained by the } \\
\text { product of exports as } \% \text { of GDP and GDP valued at } \\
\text { PPP [ } 1-7 \text { (best)] }\end{array}$ & $\begin{array}{l}\text { World } \\
\text { Economic } \\
\text { Forum }\end{array}$ \\
\hline $\begin{array}{l}\text { Infrastructure } \\
\quad \text { Index }\end{array}$ & INFR & Independent & $\begin{array}{l}\text { The higher the index the more efficient is the } \\
\text { infrastructure of a country and the more operational } \\
\text { is its economy }[1-7 \text { (best)] }\end{array}$ & $\begin{array}{l}\text { World } \\
\text { Economic } \\
\text { Forum }\end{array}$ \\
\hline $\begin{array}{l}\text { Labor Market } \\
\text { Efficiency }\end{array}$ & LME & Independent & $\begin{array}{l}\text { The effective workers allocation as well as the } \\
\text { provision of strong incentives for the employees are } \\
\text { demonstrated in this index which also performs the } \\
\text { attractiveness of a country [ } 1-7 \text { (best)] }\end{array}$ & $\begin{array}{l}\text { World } \\
\text { Economic } \\
\text { Forum }\end{array}$ \\
\hline $\begin{array}{l}\text { Unemployment } \\
\text { (Note 1) }\end{array}$ & UN & Control & $\begin{array}{c}\text { The share of the labor force that is without work but } \\
\text { available for and seeking employment. }\end{array}$ & Eurostat \\
\hline $\begin{array}{l}\text { Gross Domestic } \\
\text { Product per capita }\end{array}$ & GDPpc & Control & The GDP divided by midyear population & Eurostat \\
\hline $\begin{array}{l}\text { Export of goods \& } \\
\text { services }\end{array}$ & $\mathrm{EXP}$ & Control & $\begin{array}{l}\text { The value of all goods and other market services } \\
\text { provided to the rest of the world }\end{array}$ & Eurostat \\
\hline
\end{tabular}

Table 2. Definitions of competitiveness

\begin{tabular}{|c|c|c|c|}
\hline Perspective & Definition & Source & Details \\
\hline $\begin{array}{l}\text { Microeconomic } \\
\text { Level }\end{array}$ & $\begin{array}{c}\text { Company's ability to deal with its competitors, } \\
\text { to grow and to demonstrate sustainable } \\
\text { profitability }\end{array}$ & Law, 2009 & $\begin{array}{c}\text { The competitiveness of an enterprise is linked to } \\
\text { its ability to compete successfully with its } \\
\text { commercial rivals }\end{array}$ \\
\hline \multirow{3}{*}{$\begin{array}{c}\text { Macroeconomic } \\
\text { Level }\end{array}$} & $\begin{array}{l}\text { National competitiveness is the grid of factors, } \\
\text { policies and institutions that determine the level } \\
\text { of productivity of a country }\end{array}$ & WEF, 2007 & $\begin{array}{c}\text { The level of productivity determines the } \\
\text { sustainable level of prosperity that an economy can } \\
\text { enjoy }\end{array}$ \\
\hline & $\begin{array}{l}\text { The term competitiveness was described as the } \\
\text { capacity of a country to achieve sustainably } \\
\text { high GDP growth rates per capita }\end{array}$ & WEF, 1996 & $\begin{array}{c}\text { A more competitive economy is an economy that } \\
\text { is likely to grow faster in the medium to long term } \\
\text { timeframe }\end{array}$ \\
\hline & $\begin{array}{c}\text { The degree to which a state can, under } \\
\text { conditions of free and fair market, offer goods } \\
\text { and services that meet the criteria of } \\
\text { international markets, while maintaining and } \\
\text { increasing the real income of the people in the } \\
\text { long-term }\end{array}$ & OECD, 1996 & $\begin{array}{l}\text { In 1996, OECD defines competitiveness as } \\
\text { supporting the ability of firms, industries, regions, } \\
\text { countries or transnational regions to generate } \\
\text { relatively high levels of income and employment } \\
\text { rates, while remaining exposed to international } \\
\text { competition }\end{array}$ \\
\hline
\end{tabular}

Competitiveness is the ability of a state to create, produce and distribute products and services through international trade, making a profit
Scott \&

Lodge, 1985 U.S. competitiveness in the world economy

Literature

The ability of a state to increase its share in the international market while, at the same time, improving the living standards of its citizens
Fajnzylber, International competitiveness: agreed goal, hard 1988 
The rationale of the selection of these variables is almost straightforward; we attempt to identify whether the development of a country's financial market is related with the competitiveness of that country, especially in a period which has been characterised by a broad and global financial crisis.

Table 3. Summary statistics

\begin{tabular}{|c|c|c|c|c|c|c|}
\hline Variable & & Mean & Std.Dev. & Min & Max & Observations \\
\hline \multirow[t]{3}{*}{$\mathrm{FM}$} & Overall & 4,504 & 0,671 & 2,494 & 6,400 & $\mathrm{~N}=336$ \\
\hline & Between & & 0,543 & 3,416 & 5,468 & $\mathrm{n}=28$ \\
\hline & Within & & 0,405 & 3,335 & 6,039 & $\mathrm{~T}=12$ \\
\hline \multirow[t]{3}{*}{ UN } & Overall & 8,958 & 4,415 & 2,750 & 27,470 & $\mathrm{~N}=336$ \\
\hline & Between & & 3,378 & 5,073 & 18,440 & $\mathrm{n}=28$ \\
\hline & Within & & 2,908 & $-1,250$ & 18,620 & $\mathrm{~T}=12$ \\
\hline \multirow[t]{3}{*}{ GDPpc } & Overall & 32,700 & 21,370 & 4,490 & 118,800 & $\mathrm{~N}=336$ \\
\hline & Between & & 21,480 & 7,070 & 106,600 & $\mathrm{n}=28$ \\
\hline & Within & & 3,241 & 15,820 & 44,940 & $\mathrm{~T}=12$ \\
\hline \multirow[t]{3}{*}{ GCI } & Overall & 4,729 & 0,498 & 3,860 & 5,662 & $\mathrm{~N}=336$ \\
\hline & Between & & 0,496 & 4,010 & 5,508 & $\mathrm{n}=28$ \\
\hline & Within & & 0,099 & 4,437 & 4,991 & $\mathrm{~T}=12$ \\
\hline \multirow[t]{3}{*}{ FMI } & Overall & 4,985 & 0,787 & 2,720 & 6,562 & $\mathrm{~N}=336$ \\
\hline & Between & & 0,762 & 3,534 & 6,458 & $\mathrm{n}=28$ \\
\hline & Within & & 0,240 & 4,171 & 5,497 & $\mathrm{~T}=12$ \\
\hline \multirow[t]{3}{*}{ EXP } & Overall & 62,450 & 32,890 & 18,670 & 195,800 & $\mathrm{~N}=336$ \\
\hline & Between & & 32,250 & 24,800 & 170,600 & $\mathrm{n}=28$ \\
\hline & Within & & 8,711 & 35,490 & 105,000 & $\mathrm{~T}=12$ \\
\hline \multirow[t]{3}{*}{ INFR } & Overall & 4,973 & 0,878 & 2,561 & 6,650 & $\mathrm{~N}=336$ \\
\hline & Between & & 0,836 & 3,214 & 6,341 & $\mathrm{n}=28$ \\
\hline & Within & & 0,310 & 3,989 & 5,919 & $\mathrm{~T}=12$ \\
\hline \multirow[t]{3}{*}{ LME } & Overall & 4,460 & 0,439 & 3,290 & 5,600 & $\mathrm{~N}=336$ \\
\hline & Between & & 0,414 & 3,599 & 5,333 & $\mathrm{n}=28$ \\
\hline & Within & & 0,164 & 4,001 & 4,949 & $\mathrm{~T}=12$ \\
\hline
\end{tabular}

UN: Unemployment, total (\% of total labor force), GDPpc: GDPpc: GDP per capita (current KUS\$), GCI: Global Competitive Index 1-7 (best), FMI: Foreign market size, Index 1-7 (best), EXP: Exports of goods and services, total (\% of GDP), INFR: Infrastructure, Index 1-7 (best), LME: Labor market efficiency, Index 1-7 (best), FM: Financial Market Development, Index 1-7 (best)

Table 3 illustrates the behavior of the data covering the full-sample period. It provides the means, standard deviations, variance, minimum and maximum values for the different cross sections. As it can be seen from the Table 3 , the variation of the GCI is less than 0,01 within the years and almost 0,5 between countries. The rest of the proxy variables of financial market development are characterized by considerable variations mainly between cross sections while the FM dependent variable appears to have great variation between and within the countries and the 
time respectively. In particular, for the INFR index, the EXP and the FMI the difference between the minimum and the maximum value confirms the observed variability in a heterogeneous panel of countries, such as the one presented here.

\subsection{Methodology}

Since we have a strongly balanced panel of observations from countries spanning 12 years it is clear that there is persistence in most of our variables of interest. Given that, we make use of dynamic panel data analysis. The dynamic panel methodology allows to deal more efficiently and effectively with any econometric problems occur.

Table 4. Correlation matrix

\begin{tabular}{|c|c|c|c|c|c|c|c|c|}
\hline & FM & UN & GDPpc & GCI & FMI & EXP & INFR & LME \\
\hline $\mathrm{FM}$ & 1 & & & & & & & \\
\hline UN & $-0,5731 *$ & 1 & & & & & & \\
\hline GDPpc & $0,5026^{*}$ & $-0,3085^{*}$ & 1 & & & & & \\
\hline GCI & $0,6610^{*}$ & $-0,4307 *$ & $0,7080 *$ & 1 & & & & \\
\hline FMI & 0,0383 & $-0,0543$ & $0,2871 *$ & $0,5044 *$ & 1 & & & \\
\hline EXP & $0,1590^{*}$ & $-0,2742 *$ & $0,3994 *$ & 0,0854 & $-0,1487^{*}$ & 1 & & \\
\hline INFR & $0,3340^{*}$ & $-0,0776$ & $0,6447 *$ & $0,7880 *$ & $0,4922 *$ & $-0,0052$ & 1 & \\
\hline LME & $0,5890^{*}$ & $-0,3818 *$ & $0,4358 *$ & $0,6657^{*}$ & 0,0669 & $0,2441 *$ & $0,3181^{*}$ & 1 \\
\hline
\end{tabular}

$* 0,05$ level of significance

UN: Unemployment, total (\% of tatal labor force), GDPpc: GDPpc: GDP per capita (current KUS\$), GCI: Global Competitive Index 1-7 (best), FMI: Foreign market size, Index 1-7 (best), EXP: Exports of goods and services, total (\% of GDP), INFR: Infrastructure, Index 1-7 (best), LME: Labor market efficiency, Index 1-7 (best), FM: Financial Market Development, Index 1-7 (best)

Table 4 presents the correlation matrix among all variables used in our models. As it can be seen apart from the EXP variable, the rest of the control set variables are seriously and significant correlated with the financial market development (FM). In particular, only the unemployment rate appears to negatively correlated with the FM $(-0,573)$. In contrast, the GDPpc, the INFR and LME are positively strongly correlated $(0,503 ; 0,334$ and 0,590 respectively) with financial market development regardless of the country and the time level.

Our study contributes to the existing literature by adopting a fixed effects and a random effects model to properly account for the imposition of possible effects on financial market development. We supplement our analysis by using parametric techniques (GMM estimators) in order to compare and contrast our findings.

Before proceeding to unit root and cointegration tests we test for cross-section dependence. We use the cross-section dependence test (CD test) proposed by Pesaran (2004). CD test strongly rejects the null hypothesis of cross-section independence for all the sample variables. In face of this evidence, we proceed to test for unit roots using the so-called "second generation" tests for unit roots in panel data that are robust to cross-section dependence (see Pesaran, 2015). To examine the stationarity properties of the variables in our models we use the second-generation panel unit root tests developed by Maddala and Wu (1999) and Pesaran (2003) both suitable for balanced panel data set and cross-section dependence. The null hypothesis of a unit root (non-stationarity) cannot be rejected for all the sample variables. This means that the variables contain a unit root (e.g., integrated of order one) as expected by the visual inspection of their time series. In order to investigate whether a long-run equilibrium relationship exists among the sample variables we implement Pedroni's (1999) ADF-based and PP-based cointegration tests as well as Kao's (1999) ADF-based tests. Both tests suggest the rejection of the null hypothesis of no cointegration null at any significance level. 


\subsection{Fixed Effects Model}

The fixed effects model is simply a linear regression model in which the intercept terms vary over the individual units $i$, i.e.

$$
y_{i t}=a_{i}+x_{i t}^{\prime} \beta+\varepsilon_{i t}, \varepsilon_{i t} \sim I I D\left(0, \sigma_{\varepsilon}^{2}\right)
$$

where it is usually assumed that all $x_{i t}$ are independent of all $\varepsilon_{i t}$. We can write this in the usual regression framework by including a dummy variable for each unit $i$ in the model (Verbeek, 2008). That is,

$$
y_{i t}=\sum_{j=1}^{N} a_{j} d_{i j} x_{i t}^{\prime} \beta+\varepsilon_{i t}
$$

where $d_{i j}=0$ when $i=j$ and 0 elsewhere. We have also assumed the strictly exogenous regressors case in the conditional moments (see Woolridge, 2009). We have not assumed equal sized groups in the panel. The vector $\beta$ is a set of parameters of primary interest, $\alpha_{i}$ is the group specific heterogeneity. We have included time specific effects but, they are only tangential in what follows. Since the number of periods is usually fairly small, these can usually be accommodated simply by adding a set of time specific dummy variables to the model. Our interest here is in the case in which $N$ is too large to do likewise for the group effects.

\subsection{Random Effects Model}

It is commonly assumed in regression analysis (Verbeek, 2008) that all factors that affect the dependent variable, but that have not been included as regressors, can be appropriately summarized by a random error term. In our case, this leads to the assumption that the $\alpha_{i}$ are random factors, independently and identically distributed over individuals. Thus, we write the random effects model as:

$$
y_{i t}=\mu+a_{i}+x_{i t}^{\prime} \beta+\varepsilon_{i t}, \varepsilon_{i t} \sim I I D\left(0, \sigma_{\varepsilon}^{2}\right) ; \alpha_{i} \sim I I D\left(0, \sigma_{\alpha}^{2}\right)
$$

where $a_{i}+\varepsilon_{i t}$ is treated as an error term consisting of two components: an individual specific component, which does not vary over time, and a remainder component, which is assumed to be uncorrelated over time. It is also assumed that $a_{i}$ and $\varepsilon_{i t}$ are mutually independent and independent of $x_{j s}$ (for all $\mathrm{j}$ and $\mathrm{s}$ ).

\subsection{Arellano \& Bond - GMM}

With the intention to examine the dynamic aspects we use dynamic panel data techniques such as Difference Generalized Method of Moments (DIF-GMM) estimators attributed to Arellano and Bond, (1991) and System Generalized Method of Moments (SYS-GMM) estimators proposed by Arellano and Bover (1995) and Blundell and Bond (1998) respectively. The use of the latter is mainly justified as it improves significantly the estimates' accuracy and enlarges efficiency when the lagged dependent variables are considered as poor instruments as in the first-differenced regressors (Greene, 2003, Baltagi, 2002). As a consequence, the SYS-GMM gives more robust results than the first-differenced GLS and GMM estimation methods (Bond et al., 2001).

The GMM estimators rely on moments of the form:

$$
h(\beta)=\sum_{i=1}^{N} h_{i}(\beta)=\sum_{i=1}^{N} \Psi_{i}^{\prime} u_{i}^{\prime}(\beta)
$$

where, $\Psi_{i}$ is a $T_{i} \times p$ matrix of instruments for cross section $i$ and $u_{i}(\beta)=\left(Y_{i}-f\left(X_{i t}, \beta\right)\right)$. Specifically,

GMM minimizes the following quadratic form with respect to $\beta$ 


$$
M(\beta)=\left(\sum_{i=1}^{N} \Psi_{i}^{\prime} u_{i}(\beta)\right)^{\prime} W\left(\sum_{i=1}^{N} \Psi_{i}^{\prime} u_{i}(\beta)\right)=\zeta^{\prime(\beta)} W \zeta(\beta)
$$

where $W$ is a $p x p$ weighting matrix.

The coefficient covariance matrix is estimated as:

$$
V(\hat{\beta})=\left(G^{\prime} W G\right)^{-1}\left(G^{\prime} W \Xi W G\right)\left(G^{\prime} W G\right)^{-1}
$$

Where $\Xi$ is estimated as

$$
E\left(\zeta_{i}(\beta) \zeta_{i}(\beta)^{\prime}\right)=E\left(\Psi_{i}^{\prime} u_{i}(\beta) u_{i}(\beta)^{\prime} \Psi_{i}\right)
$$

And $G$ is a $T_{i} \times k$ matrix given as:

$$
G(\beta)=\left(-\sum_{i=1}^{N} \Psi_{i}^{\prime} \nabla f_{i}(\beta)\right)
$$

The weighting of matrix $W$ can be calculated using the White robust covariances, which are given as:

$$
\left(\frac{M^{*}}{M^{*}-k^{*}}\right)\left(\sum_{t} X_{t}^{\prime} X_{t}\right)^{-1}\left(\sum_{t} X_{t}^{\prime} \hat{u}_{t} \hat{u}_{t}^{\prime} X_{t}\right)\left(\sum_{t} X_{t}^{\prime} X_{t}\right)^{-1}
$$

The first parenthesis is an adjustment to the degrees of freedom relying on the total number of observations; $M^{*}$ is the total number of stacked observations and $k^{*}$ the number of estimated parameters. The general form of the equation estimated with panel data dynamic models is one with individual effects like the following:

$$
Y_{i t}=\lambda_{t}+\eta_{i}+\sum_{k=1}^{p} \alpha_{k} Y_{i(t-k)}+\beta^{\prime}(L) X_{i t}+v_{i t}
$$

for $i=1,2, \ldots, T$, where $\lambda_{t}$ and $\eta_{i}$ correspond to specific and individual effects, $X_{i t}$ is a vector of explanatory variables, $\beta(L)$ is a vector of associated polynomials in the lag operator and $\mathrm{q}$ is the maximum lag length. Identification of the model requires restrictions on the serial correlation of the error term $v_{i t}$ and on the properties of the independent variables $X_{i t}$ allowing only for MA or white noise errors. If the error term was originally autoregressive, the model is transformed.

Orthogonal deviations as proposed by Arellano and Bond (1988) express each observation as the deviation from the average of future observations in the sample and weight each deviation to standardize the variance:

$$
x_{i t}^{*}=\left[x_{i t}-\left(x_{i(t+1)}+\ldots+x_{i T}\right) /(T-t)\right] \sqrt{(T-t)} / \sqrt{T-t+1}
$$

for $t=1,2, \ldots, T-1$.

The $T_{i}-q$ equations for individual unit $i$ can be written as:

$$
Y_{i}=\delta w_{i}+d_{i} \eta_{i}+v_{i}
$$

where $\delta$ is a parameter vector including $\alpha_{\kappa}, \beta$ and $\lambda$; and $w_{i}$ is a data matrix containing the time series of the lagged endogenous variables, the $x^{\prime} \mathrm{s}$, and the time dummies. The $d_{i}$ is a $\left(T_{i}-q\right) \times 1$ vector of ones. Following Arellano and Bond (1998), linear GMM estimators of $\delta$ may be computed by the following expression: 


$$
\hat{\delta}=\left[\left(\sum_{i} w_{i}^{* \prime} Z_{i}\right) \cdot \frac{1}{\frac{1}{N} \sum_{i} Z_{i}^{\prime} H_{i} Z_{i}} \cdot\left(\sum Z_{i}^{\prime} w_{i}^{*}\right)\right]^{-1} \cdot\left(\sum_{i} w_{i}^{* \prime} Z_{i}\right) \frac{1}{\frac{1}{N} \sum_{i} Z_{i}^{\prime} H_{i} Z_{i}}\left(\sum_{i} Z_{i}^{\prime} Y_{t}^{*}\right)
$$

where $w_{i}^{*}$ and $Y_{i}^{*}$ denote some transformation of $w_{i}$ and $Y_{i}$ such as first differences, orthogonal deviations or levels. $Z_{i}$ is the matrix of instrumental variables and $H_{i}$ is an individual specific weighting matrix. We may have one-step estimates, which use some known matrix as the choice for $H_{i}$. For a first - difference procedure, the one-step estimator uses $H_{i}$, while for orthogonal deviations or for a levels procedure the one-step estimator sets $H_{i}$ to an identity matrix. If the $v_{i t}$ are heteroskedastic, a two-step estimator is used.

\section{Results and Implications}

\subsection{Results}

From the regressions run, we realize that the financial market development is positively correlated with the global competitiveness index (GCI) at all significance levels with all three approaches, i.e. fixed effects, random effects and Arellano-Bond. It is positively correlated with the GDP per capita will all three methods as well; however, different significance levels are observed. Namely, the financial market development is positively correlated with the GDP per capita at all significance levels when the random effects and the Arrelano-Bond methods are used and at the $10 \%$ significance level when the fixed effects method is employed.

The financial market development is negatively correlated with the unemployment rate also with all three models. It is negatively correlated with the fixed effects and random effects models at all significance levels, whereas it is negatively correlated with the Arellano-Bond model at the 5\% significance level. It is negatively correlated with the foreign market size index and the exports (as a percent of GDP) at all significance levels with all three models, i.e. fixed effects, random effects and Arellano-Bond. It is negatively correlated with the infrastructure index at all significance levels with the Arellano Bond approach and at the 5\% significance level with the random effects approach.

The constant term is statistically significant at all levels with all three methods. For the remaining of the variables (per approach) there seems to be no statistical significance; however, they were incorporated in the model as they contribute to the goodness of fit.

\subsection{Interpretation and Implications}

The regressions ran indicate that when the GCI is tested, there is a positive correlation with the financial market development. This finding is probably anticipated, as countries that exhibit high competitiveness have at the same time achieved high levels of financial market development. There are a number of reasons that could explain this. High competitiveness fosters the efficiency of the financial sector, attracts domestic and foreign resources and directs them effectively to entrepreneurial or investment projects. Highly competitive economies most likely have sophisticated financial markets, sound banking sector and well regulated capital and OTC markets. They have secured transparency and inspire trust to all the interested stakeholders. Consequently, their financial markets enjoy higher development levels.

The same is observed when the GDP per capita is considered. A potential interpretation is that countries that are more prosperous have more resources flown into the financial markets, which as a results become more mature and developed. Inevitably the banking sector is comparatively more solid. The citizens could be more demanding and consequently the supervision, regulation, transparency and trustworthiness are at higher levels compared to countries that have a lower GDP per capita.

When we look at the unemployment rate, we realize that it is negatively correlated with the financial market development. The rationale is probably symmetric with the aforementioned one; higher unemployment most likely leads to lower flows towards the financial markets from the domestic investors and is potentially associated with less entrepreneurial and investment projects and therefore less sophisticated and less developed financial markets. 
However, there is a negative correlation of the financial market development and the foreign market size and exports as well as infrastructure. One would probably expect the opposite, i.e. that higher foreign market size and exports or even infrastructure would lead to highly developed financial markets. Looking for potential interpretations we realize that our period of examination (2006 to 2017) is around - and thus influenced - by the 2008 crisis. Consequently, most of the country's experiences decreasing financial market development (Figure 2), whereas their exports and foreign market size did not drop; it remained stable or even increased (Figure 1). The drop of the financial market development could be explained by the impact the crisis had in the financial markets, which for some countries where rather turbulent. At the same time the banking sector is still not as solid as it was thought to be; in some cases, it is still rather fragile. This has diminished the trustworthiness towards the financial and capital markets and has led to lower investment flows. On the contrary, it seems that exports and foreign market size have increased, especially in the post crisis period. The same holds true for the infrastructure index. It could be that the countries paid more attention in strengthening their economies by performing additional exports and addressing the foreign markets on one hand and directing public spending towards infrastructure on the other hand. This is not a paradox; countries needed to boost their economies, reduce unemployment - that in some cases skyrocketed - and create conditions that would help them whether the crisis. This was done by acting outside and inside their borders. The former increased exports and foreign market size. The latter led to increased infrastructure. Consequently, all three of them improved for the majority of the countries over the years. Besides the explanation we offer though, we feel that these variables need to be further researched.

Impacting the GDP per capita and the unemployment may be a challenging target for a country. Steering though the (perceived) competitiveness of the country is not beyond reach. The common playing field of the European Union definitely helps in this direction. Consequently, policy makers can find value in the aforementioned findings as evidence is provided that there are ways to increase the financial markets development. No need to say that when this is achieved, other metrics of the economy are expected to improve, as a solid banking sector and a well-regulated, trustworthy financial market can attract additional investors and entrepreneurs; this in its turn is anticipated to be beneficial for the economy as a whole, potentially reducing the unemployment rate and increasing the GDP per capita.

Table 5. Regression summary

\begin{tabular}{ccccc}
\hline & Pooled OLS & Fixed Effects & Random Effects & Arellano - Bond GMM \\
& $\mathrm{b} / \mathrm{se}$ & $\mathrm{b} / \mathrm{se}$ & $\mathrm{b} / \mathrm{se}$ & $\mathrm{b} / \mathrm{se}$ \\
\hline UN & $-0.032^{* * *}$ & $-0.043^{* * *}$ & $-0.045^{* * * *}$ & $-0.027^{* *}$ \\
& $(0.01)$ & $(0.01)$ & $(0.01)$ & $(0.01)$ \\
GDPpc & $0.004^{* *}$ & $0.022^{*}$ & $0.015^{* * *}$ & $0.039 * * *$ \\
& $(0.00)$ & $(0.01)$ & $(0.00)$ & $(0.00)$ \\
GCI & $1.209 * * *$ & $1.077 * * *$ & $1.079 * * *$ & $0.821^{* * *}$ \\
& $(0.12)$ & $(0.29)$ & $(0.24)$ & $(0.29)$ \\
FMI & $-0.272 * * *$ & $-0.514 * * *$ & $-0.454 * * *$ & $-0.543 * * *$ \\
& $(0.03)$ & $(0.13)$ & $(0.07)$ & $(0.06)$ \\
EXP & $-0.002 *$ & $-0.013 * * *$ & $-0.009 * * *$ & $-0.011^{* * *}$ \\
& $(0.00)$ & $(0.00)$ & $(0.00)$ & $(0.00)$ \\
INFR & $-0.240 * * *$ & -0.196 & $-0.257 * *$ & $-0.592^{* * *}$ \\
& $(0.05)$ & $(0.13)$ & $(0.10)$ & $(0.12)$ \\
LME & -0.00900 & -0.176 & -0.131 & 0.0280 \\
& $(0.09)$ & $(0.16)$ & $(0.16)$ & $(0.11)$
\end{tabular}




\begin{tabular}{ccccc} 
constant & $1.624 * * *$ & $4.229 * * *$ & $4.002 * * *$ & $5.807 * * *$ \\
& $(0.35)$ & $(1.27)$ & $(0.66)$ & $(0.80)$ \\
\hline R-sqr & 0.646 & 0.639 & & \\
Dfres & 328 & 27 & &. \\
BIC & 381.1 & 43.50 &. &
\end{tabular}

UN: Unemployment, total (\% of tatal labor force), GDPpc: GDPpc: GDP per capita (current KUS\$), GCI: Global Competitive Index 1-7 (best), FMI: Foreign market size, Index 1-7 (best), EXP: Exports of goods and services, total (\% of GDP), INFR: Infrastructure, Index 1-7 (best), LME: Labor market efficiency, Index 1-7 (best), FM: Financial Market Development, Index 1-7 (best)
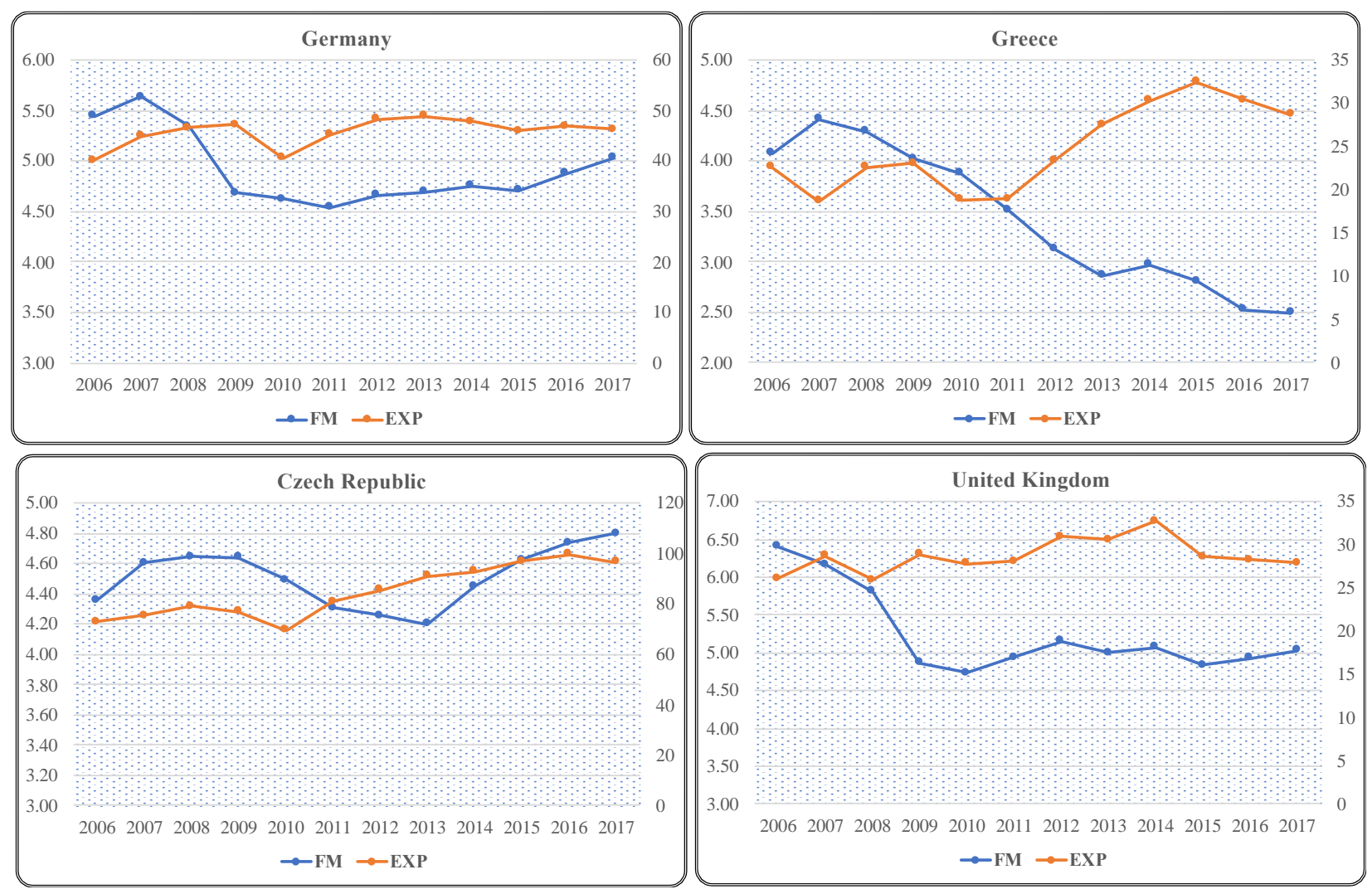

Figure 1. Financial Market Development and Exports of Goods and Services (\% of GDP) 


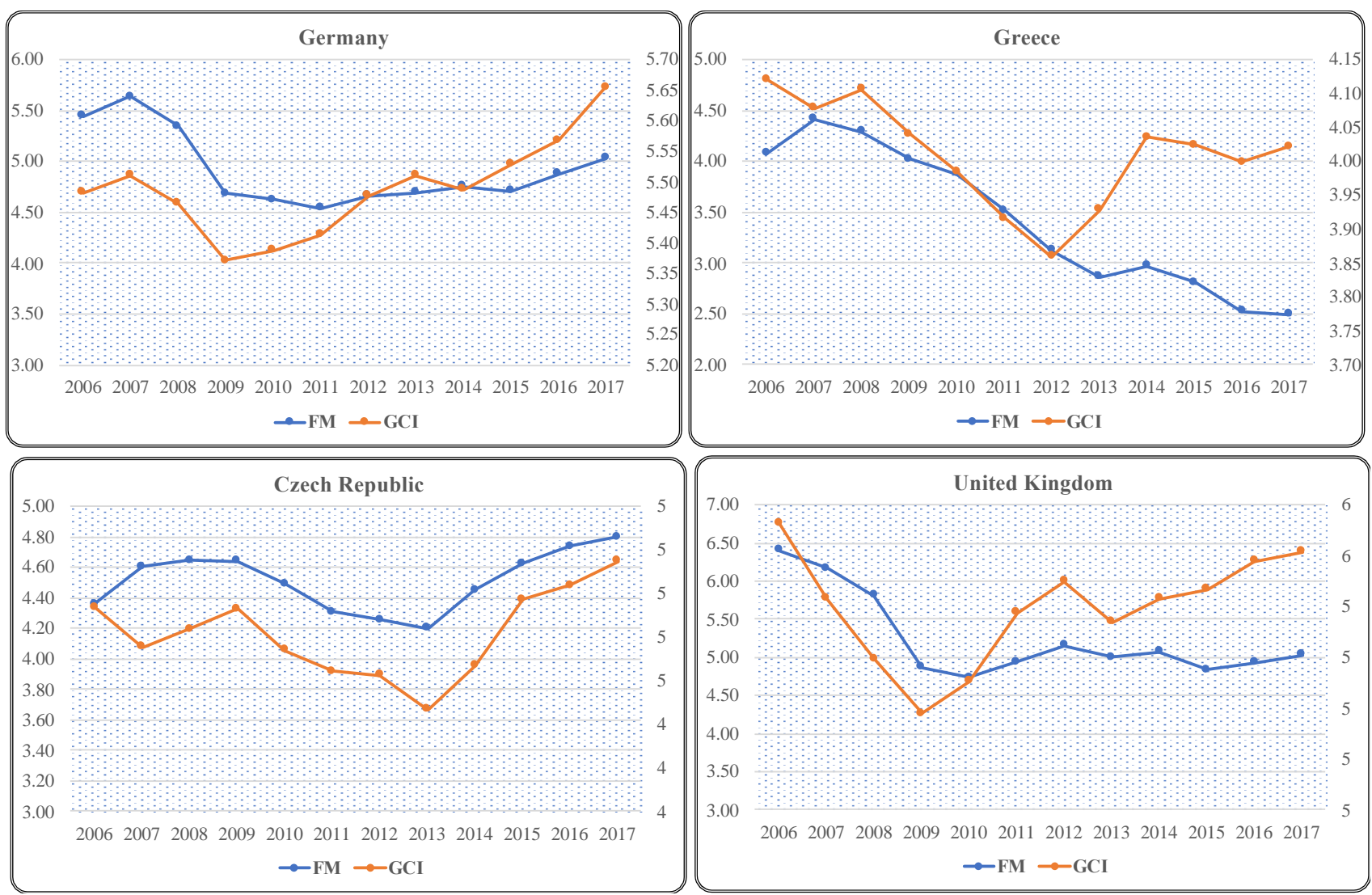

Figure 2. Financial Market Development and Global Competitive Index

\section{Future Research}

In this paper we used a set of competitiveness factors to demonstrate the dependence with the development of a country's financial market from competitiveness. However, as noted by our findings, the impact of some variables needs to be reevaluated. More precisely, we deem necessary to revisit the (co)relation of the financial markets development with the foreign market size, the exports and the infrastructure. Furthermore, we would like to study the link between competitiveness and the equity or debt markets separately. In addition, provided we gain access to data that go several years before the 2008 financial crisis, we will distinguish the periods before, during and after the crisis, especially in reference to the aforementioned variables. These targets lie beyond the scope of this paper, which focuses specifically in times of crisis, and is thus left for future research. We consider among future research venues the study of the opposite relation, i.e. the impact of financial market development of competitiveness.

\section{Conclusions}

The development and the performance of financial markets in the European Union is of high interest, as they can become a source of funding for enterprises and a source of income for potential investors. The investment attractiveness of a country is a proof of trust by investors. A clear example of this outcome is Greece, a country that seems to have suffered the most from the financial crisis. Investors have stayed for many years out of the financial markets of the country, which may have assisted in extending the crisis period for the country and in making it even harsher.

In this paper we found evidence that there is a clear link between the financial market development of a country and its competitiveness as measured by the Global Competitiveness Index, the GDP per capita and the (un)employment. This indicates that the competent authorities of a country need to seriously consider its competitiveness, as measured by these variables, in order to secure the desired financial market growth. Consequently, they need to review their globally perceived competitiveness, their level of GDP per capita and their (un)employment rate. Greece is again a member state to which this approach is extremely relevant. We found unexpected direction of the correlation between financial market development and the foreign market size, the exports and the infrastructure, which although was explainable, needs to be further investigated. 


\section{References}

Acemoglu, D., Johnson, S., \& Robinson, J. (2002). Reversal of fortune: Geography and institutions in the making of the modern world distribution of income. Quarterly Journal of Economics, 117(4), 1231-1294. https://doi.org/10.1162/003355302320935025

Acs, Z., \& Szerb, L. (2009). The Global Entrepreneurship Index (Jena Research papers). Jena: Max Planck Institute of Economics.

Alomari, M. W., Marashdeh, Z., \& Bashayreh, A. G. (2019). Contribution of financial market development in competitiveness growth. Cogent Economics \& Finance, $7(1), \quad$ 1-19. https://doi.org/10.1080/23322039.2019.1622483

Arellano, M., \& Bond, S. (1988). Dynamic panel data estimation using PPD: a guide for users. London: Institute for Fiscal Studies.

Arellano, M., \& Bond, S. (1991). Some tests of specification for panel data: Monte Carlo evidence and an application to employment equations. Review of Economics and Statistics, 58, 277-297. https://doi.org/10.2307/2297968

Baltagi, B. H., \& Li, D. (2002). Series estimation of partially linear panel data models with fixed effects. Annals of Economics and Finance, 3(1), 103-116.

Barro, R. (1991, May). Economic Growth in a Cross Section of Countries. The Quarterly Journal of Economics, 106(2), 407-443. https://doi.org/10.2307/2937943

Beck, T., Levine, R., \& Loayza, N. (2000). Finance and the Sources of Growth. Journal of Financial Economics, 58(1-2), 261-300. https://doi.org/10.1016/S0304-405X(00)00072-6

Bosma, N., \& Levie, J. (2010). Global entrepreneurship monitor, 2009 executive report. Babson Park, MA, London: Babson College, London Business School, GERA.

Boyd, J. H., \& Jalal, A. M. (2012). A new measure of financial development: Theory leads measurement. Journal of Development Economics, 99(2), 341-357. https://doi.org/10.1016/j.jdeveco.2012.04.002

Boyd, J. H., Levine, R., \& Smith, B. D. (2001). The impact of inflation on financial sector performance. Journal of monetary Economics, 47(2), 221-248. https://doi.org/10.1016/S0304-3932(01)00049-6

Buckley P. J., Pass, C. L., \& Prescott, K. (1988). Measures of International Competitiveness: A Critical Survey. Journal of Marketing Management, 4(2), 175-200. https://doi.org/10.1080/0267257X.1988.9964068

Buckley, P. J. (1990). Problems and developments in the core theory of international business. Journal of International Business Studies, 21(4), 657-65. https://doi.org/10.1057/palgrave.jibs.8490346

Calderon, C., \&Serven, L. (2004). The effects of infrastructure development on growth and income distribution. World Bank Policy Research Working Paper No. 3400. Washington, DC: World Bank. https://doi.org/10.1596/1813-9450-3400

Cohen S. S., \& Zysman, J. (1994). Manufacturing Matters. Basic Books New York.

De Haas, R. (2001). Financial Development and Economic Growth in Transition Economies: A Survey of the Theoretical and Empirical Literature. Research Series Supervision, Netherlands Central Bank.

Ezeala-Harrison, F. (1999). Theory and Policy of International Competitiveness. New York: Plaeger.

Fagerberg, J. (1988). Technology and Competitiveness. Oxford Review of Economic Policy, 12(3), 39-51. https://doi.org/10.1093/oxrep/12.3.39

Francis, A. (1989). The concept of competitiveness. In A. Francis, \& P. Tharakan (Eds.), The Competitiveness of European Industry (pp. 5-20). London: Routledge.

Goodfriend, M. (2007). How the world achieved consensus on monetary policy. Journal of Economic Perspectives, 21(4), 47-68. https://doi.org/10.1257/jep.21.4.47

Govindarajan, \& Gurta, A. K. (2001). The Quest for Global Dominance. San Francisco: Jossey - Bass.

Greene, W. H. (2003). Econometric analysis. Pearson Education India.

Harrison, A. (1996). Openness and growth: A time-series, cross-country analysis for developing countries. Journal of Development Economics, 48, 419-447. https://doi.org/10.1016/0304-3878(95)00042-9 
Jochem, A. (2016). International Financial Competitiveness and Incentives to Foreign Direct Investment. JahrbücherfürNationalökonomie und Statistik, 230(1), 42-58. https://doi.org/10.1515/jbnst-2010-0104

Jones, P. T., \& Teece, D. J. (1988). The Research Agenda on Competitiveness. In A Furino (Ed.), Cooperation and Competition in the Global Economy. Cambridge: Ballinger Publishing Company.

Kao, C., \& Chiang, M. H. (2000). On the estimation and inference of a cointegrated regression in panel data. Advances in Econometrics, 15, 179-222. https://doi.org/10.1016/S0731-9053(00)15007-8

King, M. A. (1994). Debt Deflation: Theory and Evidence. European Economic Review, 38, 419-445. https://doi.org/10.1016/0014-2921(94)90083-3

King, R. G., \& Levine, R. (1993). Financial intermediation and economic development. Capital Markets and Financial Intermediation, 156-189. https://doi.org/10.1017/CBO9780511752056.011

King, R. G., \& Levine, R. (1993a). Finance and Growth: Schumpeter Might be Right. Quarterly Journal of Economics, 108, 717-38. https://doi.org/10.2307/2118406

King, R. G., \&Levine, R. (1993b). Finance, Entrepreneurship and Growth: Theory and Evidence. Journal of Monetary Economics, 32, 513-42. https://doi.org/10.1016/0304-3932(93)90028-E

Levine, R. (2004). Finance and Growth: Theory and Evidence. NBER Working Paper, No. 10766, Cambridge, MA: National Bureau of Economic Research. https://doi.org/10.3386/w10766

Levine, R., Loayza, N., \& Beck, T. (2000a). Financial Intermediation and Growth: Causality and Causes. Journal of Monetary Economics, 46, 31-77. https://doi.org/10.1016/S0304-3932(00)00017-9

Levine, R., Loayza, N., \& Beck, T. (2000b). Finance and the Sources of Growth. Journal of Financial Economics, 58, 261-30. https://doi.org/10.1016/S0304-405X(00)00072-6

Lozano-Vivas, A., \& Pastor, J. T. (2006). Banking and Economic Activity Performance: An Empirical Study at the Country Level. The Manchester School, 74(4), 469-482. https://doi.org/10.1111/j.1467-9957.2006.00504.x

Maddala, G. S., \& Wu, S. (1999). A Comparative Study of Unit Root Tests With Panel. https://doi.org/10.1111/1468-0084.61.s1.13

Martin C. A. (2001). Capital investment in organizational capabilities. Strategic Management Journal, 21 (special issue), 955-959. https://doi.org/10.1002/1097-0266(200010/11)21:10/11<955::AID-SMJ136>3.0.CO;2-S

McKinnon, R. I. (1973). Money and Capital Economic Development. Brookings Institution, Washington DC.

Miller, T., Kim, A., \& Holmes, K. R. (2014). 2014 Index of economic freedom. Washington, DC: The Heritage Foundation.

Mitchell, W. (2000). Path-dependent and path-breaking change: Reconfiguring business resources following acquisitions in the USA medical sector, 1978-1995. Strategic Management Journal, 21 (special issue), 1061-1081. https://doi.org/10.1002/1097-0266(200010/11)21:10/11<1061::AID-SMJ116>3.0.CO;2-G

Nelson, R. (1992). Recent Writings on Competitiveness: Boxing the Compass. California Management Review, winter, 127-13. https://doi.org/10.2307/41166697

OECD, TEP. (1992). The Technology/Economy Programme Technology and the economy, The Key Relationships. Paris, OECD.

OECD. (2017). Economic Outlook No 101 - June 2017. Retrieved September 1, 2017, from http://stats.oecd.org

Pedroni, P. (1999). Critical values for cointegration tests in heterogeneous panels with multiple regressors. Oxford Bulletin of Economics and Statistics, 61(S1), 653-670. https://doi.org/10.1111/1468-0084.61.s1.14

Pesaran, M. H. (2003). A Simple Panel Unit Root Test in the Presence of Cross Section Dependence. Cambridge Working Papers in Economics 0346, Faculty of Economics (DAE), University of Cambridge. https://doi.org/10.2139/ssrn.457280

Pesaran, M. H. (2004). General Diagnostic Tests for Cross Section Dependence in Panels. Cambridge Working Papers in Economics 0435. Faculty of Economics (DAE), University of Cambridge.

Pesaran, M. H. (2015). Time Series and Panel Data Econometrics. Oxford University Press. https://doi.org/10.1093/acprof:oso/9780198736912.001.0001 
Porter, M. E. (2011). Competitive advantage of nations: creating and sustaining superior performance. Simon and Schuster.

Rebernik, M., Tominc, P., Crnogaj, K., S irec, K., BradacHojnik, B., \& Rus, M. (2015). Pomanjkanjevitalnostislovenskegapodjetnis ${ }^{2}$ tva $\quad-\quad$ GEM Slovenija 2014. Maribor: Ekonomsko-poslovnafakulteta.

Reiljan, J., Hinrikus, M., \& Ivanov, A. (2000) Key Issues in Defining and Analyzing the Competitiveness of a Country. Tartu: University of Tartu.

Reinert, E. S. (1995). Competitiveness and its predecessors - a 500-year cross-national perspective. Structural change and economic dynamics, (6), 23-42. https://doi.org/10.1016/0954-349X(94)00002-Q

Reinhart, C. M., \& Rogoff, K. S. (2010). Growth in a time of debt. American Economic Review: Paper and Proceedings, 100, 573-578. https://doi.org/10.1257/aer.100.2.573

Reve T., \& Mathiensen, L. (1994). European Industrial Competitiveness. Bergen Foundation for Research in Economics and Business Administration.

Rioja, F., \& Valev, N. (2004). Finance and the Sources of Growth at Various Stages of Economic Development. Economic Inquiry, 42(1), 27-40. https://doi.org/10.1093/ei/cbh049

Rodrik, D., Subramanian, A., \& Trebbi, F. (2002). Institutions rule: The primacy of institutions over geography and integration in economic development. Mimeo: Harvard University. https://doi.org/10.3386/w9305

Scott, B., \& Lodge, G. (1985). U.S. competitiveness in the world economy. Boston: Harvard Business School Press, p. 340.

Shaw, E. S. (1973). Financial Deepening Economic Development. Oxford University Press, New York.

Squalli, J., Wilson, K., \& Hugo, S. (2008). An analysis of growth competitiveness. International Review of Applied Economics, 22(1), 105-126. https://doi.org/10.1080/02692170701745978

Tapscott, D. (2001). Rethinking strategy in a networked world. Strategy \& Business, 34-41. https://doi.org/10.1145/763893.763743

Temple, J. (2000). Inflation and growth: Stories short and tall. Journal of Economic Surveys, 14(4), 395-426. https://doi.org/10.1111/1467-6419.00116

The World Bank. (2017). Indicators. Retrieved August 30, 2017, from https://data.worldbank.org/indicator

Verbeek, M. (2008). A guide to modern econometrics. John Wiley \& Sons.

Woolridge, J. M. (2009). Introductory Econometrics: A Modern Approach, (5e). South-Western, Michigan State University, 378, p. 57.

Yap, J. T. (2004). A Note on the Competitiveness Debate. Discussion Paper Series No. 2004-39, Phlippine Institute for Development Studies, pp. 1-22.

\section{Note}

Note 1. As for the limitations of this study, it should be mentioned that the definitions of labor force and unemployment may differ by country; however, for this study we consider the European countries where there are not any fundamental differences

\section{Copyrights}

Copyright for this article is retained by the author(s), with first publication rights granted to the journal.

This is an open-access article distributed under the terms and conditions of the Creative Commons Attribution license (http://creativecommons.org/licenses/by/4.0/). 